\title{
A SLOW OUTWARD CURRENT AND A HYPOOSMOLALITY INDUCED ANION CONDUCTANCE IN EMBRYONIC CHICKEN OSTEOCLASTS
}

\author{
Z. Krasznai, ${ }^{1 *}$ F. Weidema, ${ }^{3}$ D. L. Ypey, ${ }^{3}$ S. Damuanovich, ${ }^{1}$ \\ R. GÁSPÁR JR. ${ }^{1}$ and TERÉZ MÁriÁN ${ }^{2}$ \\ ${ }^{1}$ Department of Biophysics and Cell Biology, Faculty of Medicine, Medical and Health Science \\ Center, University of Debrecen, Debrecen, ${ }^{2}$ PET Center, Faculty of Medicine, \\ Medical and Health Science Center, University of Debrecen, Debrecen, Hungary \\ ${ }^{3}$ Department of Physiology and Physiological Physics, Leiden University, Leiden, The Netherlands
}

(Received: March 24, 2000; accepted: December 12, 2000)

In this paper we report on a hypoosmolality induced current, $\mathrm{I}_{\mathrm{osmo}}$, in embryonic chicken osteoclasts, which could only be studied when blocking a simultaneously active, unidentified slow outward current, $I_{\text {slo. }}$.

$I_{\text {slo }}$ was observed in all of the examined cells when both the intracellular and extracellular solutions contained sodium as the major cation and no potassium. The current was outwardly rectifying and activated at membrane potentials more positive than $+44 \pm 12 \mathrm{mV}(\mathrm{n}=31)$. The time to half activation of the current was also voltage dependent and was $350 \mathrm{~ms}$ at $\mathrm{V}_{\mathrm{m}}=+80 \mathrm{mV}$, and $78 \mathrm{~ms}$ at $\mathrm{V}_{\mathrm{m}}=+120 \mathrm{mV}$. The current did not inactivate during periods up to $5 \mathrm{~s}$. Extracellular 4-AP $(5 \mathrm{mM})$, TEA $(5 \mathrm{mM})$ and $\mathrm{Ba}^{2+}$ $(1 \mathrm{mM})$, blockers of $\mathrm{K}^{+}$conductances in chicken osteoclasts, did not influence $\mathrm{I}_{\text {slo. }}$. However, $\mathrm{I}_{\text {slo }}$ was inhibited by $50 \mu \mathrm{M}$ extracellular verapamil, which allowed us to study $\mathrm{I}_{\text {osmo }}$ in isolation.

Exposure of the osteoclasts to hypotonic solution resulted in the development of a depolarization activated $\mathrm{I}_{\text {osmo }}$. It developed after a 1-min delay and reached its maximum within 10 minutes. Half-maximal activation occurred after $4.4 \pm 0.9 \mathrm{~min}(\mathrm{n}=9)$. The current activated within a few ms upon depolarization and did not inactivate during at least $5 \mathrm{sec}$. $\mathrm{I}_{\text {osmo }}$ reversed around the calculated Nernst potential for $\mathrm{Cl}^{-}\left(\mathrm{E}_{\mathrm{Cl}}=+7.3 \mathrm{mV}\right.$ and $\left.\mathrm{V}_{\text {rev }}=+5.4 \pm 3.6 \mathrm{mV}, \mathrm{n}=9\right)$. The underlying conductance, $\mathrm{G}_{\text {osmo }}$ exhibited moderate outward rectification around $0 \mathrm{mV}$ in symmetrical $\mathrm{C1}^{-}$solutions. Ion substitution experiments showed that $\mathrm{G}_{\text {osmo }}$ is an anion conductance with $\mathrm{P}_{\mathrm{Cl}} \approx \mathrm{P}_{\mathrm{F}}>\mathrm{P}_{\text {gluc }} \gg \mathrm{P}_{\mathrm{Na}}$. $\mathrm{I}_{\text {osmo }}$ was blocked by $0.5 \mathrm{mM}$ SITS but $50 \mu \mathrm{M}$ verapamil, $5 \mathrm{mM}$ TEA, $5 \mathrm{mM} 4-\mathrm{AP}, 1 \mathrm{mM} \mathrm{Ba}^{2+}, 50 \mu \mathrm{M}$ cytochalasin D and $0.5 \mathrm{mM}$ alendronate did not have any effect on the current.

$\mathrm{Cl}^{-}$currents have been implicated in charge neutralization during osteoclastic acid secretion for bone resorption. The present results imply that osmolality may be a factor controlling this charge neutralization.

Keywords: Osteoclast - anion conductance - hypoosmolality - bone resorption

\section{INTRODUCTION}

Bone is a hard but living tissue, in a dynamical balance of bone production by osteoblasts and bone resorption by osteoclasts. Osteoporosis of elderly women arises from an incompletely balanced osteoclasts activity resulting in a continuous loss of bone mass. Despite intensive biochemically oriented basic and clinical research to

*Corresponding author; E-mail: krasznai@jaguar.dote.hu 
uncover cellular control mechanism of bone cell activity, the basic mechanism are still not well understood. Osteoclasts are large, multinucleated cells formed by fusion of mononucleated precursors that originate from a hemapoitic progenitor. Bone resorption by osteoclasts is required during skeletal growth or remodeling. Osteoclasts form a specialized sealing zone at the periphery of their contact with the bone or calcified tissue, to establish a resorption lacuna [31]. Inside this lacuna, the mineral component of bone, mainly hydroxyapatit, is dissolved by acidification and the organic bone matrix is digested by secreted enzymes.

The acidification is carried out by an electrogenic proton pump localized in the ruffled membrane [2]. Electrophysiological considerations suggest that the pump activity must be controlled by other ion transport mechanisms to maintain electroneutrality. The efflux of positive charged protons could be compensated by either an influx of cations or an efflux of anions.

With this view in mind ion channels in the osteoclasts membrane have been characterised and a broad spectrum of ion channel types has been found in chicken osteoclasts $[12,21,22,34,36]$, including three types of $\mathrm{K}^{+}$channels, a stretch-activated (SA) channel, a high conductance $\mathrm{Cl}^{-}$channel and a fast $\mathrm{Na}^{+}$channel. The high-conductance anion-channel has only been found in excised patches, but never under whole cell conditions where the transmembrane proteins are practically untouched. Blair et al. $[4,5]$ demonstrated that the electrogenic proton pump of the avian osteoclasts ruffled membrane is charge coupled to a passive $\mathrm{Cl}^{-}$permeability in the same membrane. Sims et al. [29] reported an outwardly rectifying $\mathrm{Cl}^{-}$current in $30 \%$ of the rat osteoclasts studied. The current reversed at the chloride equilibrium and was 4,4'-diisothiocyaniostilbene-2,2'-disulphonic acid (DIDS) and 4-acetamido-4'-isothiocyanostilbene-2-2'-disulphonic acid (SITS) sensitive. They conclude that the outwardly rectifying chloride current plays an essential physiological role, i.e. dissipating the potential arising from electrogenic proton transport. Steinert and Grissmer [30] reported on a $\mathrm{K}^{+}$or hypotonicity induced $\mathrm{Cl}^{-}$current in human osteoblasts and human leukaemic T lymphocytes while [9] on the osmosensitivity of the hyperpolarization induced chloride current in human intestinal T84 cells. Up to now there is no report about the existence of whole-cell chloride current in chicken osteoclasts.

Here we report on a new chloride conductance and a slowly activating outward current in embryonic chicken osteoclasts.

\section{MATERIALS AND METHODS}

Osteoclasts (OC) were isolated from the femora and tibiae of 18 days old chicken embryos. The osteoclasts were cultured in Iscove's Modified Dulbecco's Medium (Difco), supplemented with 10\% fetal calf serum (Gibco), $10 \mathrm{mM} \mathrm{HEPES,} \mathrm{pH}=6.9$, $85 \mu \mathrm{g} / \mathrm{ml}$ gentamicin and $584 \mu \mathrm{g} / \mathrm{ml}$ glutamine as described elsewhere [22]. Prior to the experiments, the cells were rinsed and placed into extracellular solutions (ECS), see Table 1. Electrodes were pulled from borosilicate glass (GC150TF-15, Clark, $\mathrm{UK}$ ) and had a resistance of 2-5 MOhm after heat polishing. The software program 
"pClamp" (Axon, USA) run on an AT-IBM computer equipped with a Labmaster analog-digital converter, was used to apply voltage-protocols to, and record currents from the cells. All recordings were made at room temperature $\left(20-24{ }^{\circ} \mathrm{C}\right)$. Currents were measured both on conventional whole-cell (WC) and nystatin whole-cell (nysWC) configuration of the patch-clamp technique $[14,17]$ with a RK300 patch clamp amplifier (Biologic, France). Pipettes were filled with intracellular solutions (ICS) with $0 \mathrm{mM} \mathrm{K}^{+}$to minimize the contribution of $\mathrm{K}^{+}$conductances. Compositions of ICS solutions are given in Table 1. Most recording were made in nys-WC configuration. The nystatin incorporation was tested by giving short pulses to monitor the increase in the peak of the transient capacitive current during the decline of the series resistance. A final confirmation of a good nystatin incorporation was the appearance of the inward rectifier (Gki), when the cells were bathed in S-ECS. In addition, series resistance compensation was used on the patch-clamp amplifier, resulting in corrected Rs values $<10 \mathrm{MOhm}$.

The bath was connected via an ECS-containing agar salt bridge to an ECS-containing pool with a grounded reference $\mathrm{Ag} / \mathrm{AgCl}$ electrode to prevent offset voltage changes at the interface between the reference electrode and the test solutions. Junction potential changes at the bridge-bath interface due to the exchange of bath solutions with different anion concentrations were measured (a few $\mathrm{mV}$ ) and corrected for in the calculations of the reversal potentials.

$\mathrm{NaCl}$, Na-glutamate, $\mathrm{KCl}, \mathrm{CaCl}_{2}, \mathrm{MgCl}_{2}$, sucrose and the inorganic phosphate salts were purchased from Merck (Darmstadt, Germany), Na-gluconate from K\&K Laboratories (Cleveland, OH, USA), ethylene glycol-bis( $\beta$-aminoethyl ether)$\mathrm{N}, \mathrm{N}, \mathrm{N}^{1}, \mathrm{~N}^{1}$-tetraacetic acid (EGTA) was purchased from Sigma (St. Luis, MO. USA) and the N-(2-hydroxyethyl)-piperazine-N'-2-ethanesulfonic acid (HEPES), from Serva (Heidelberg, Germany). The bisphosphonate alendronate was kindly provided by the Merck Research Laboratories, West Point, PA, USA. Verapamil (Isoptin, ver-

Table 1

Compositions of the solutions (in $\mathrm{mM}$ ) used in the experiments

\begin{tabular}{lrrrrrrrr}
\hline & S-ECS & Na-ECS & $\begin{array}{c}\text { Fluoride- } \\
\text { ECS }\end{array}$ & $\begin{array}{c}\text { Sucrose- } \\
\text { ECS }\end{array}$ & $\begin{array}{c}\text { Gluconate- } \\
\text { ECS }\end{array}$ & Na-ICS & S-ICS & $\begin{array}{c}\text { Gluconate- } \\
\text { ICS }\end{array}$ \\
\hline $\mathrm{KCl}$ & 5 & 0 & 0 & 0 & 0 & 0 & 140 & 0 \\
$\mathrm{NaCl}$ & 145 & 150 & 0 & 15 & 0 & 150 & 5 & 30 \\
$\mathrm{CaCl}_{2}$ & 1 & 1 & 1 & 1 & 1 & 4 & 4 & 4 \\
$\mathrm{MgCl}_{2}$ & 1 & 1 & 1 & 1 & 1 & 1 & 1 & 1 \\
$\mathrm{EGTA}$ & 0 & 0 & 0 & 0 & 0 & 10 & 10 & 10 \\
$\mathrm{HEPES}$ & 10 & 10 & 10 & 10 & 10 & 10 & 10 & 10 \\
Sucrose & 0 & 0 & 0 & 270 & 0 & 0 & - & 0 \\
NaF & 0 & 0 & 150 & 0 & 0 & 0 & - & 0 \\
Na-Gluconate & 0 & 0 & 0 & 0 & 150 & 0 & - & 120 \\
pH & 7.2 & 7.2 & 7.2 & 7.2 & 7.2 & 7.2 & 7.2 & 7.2 \\
\hline
\end{tabular}



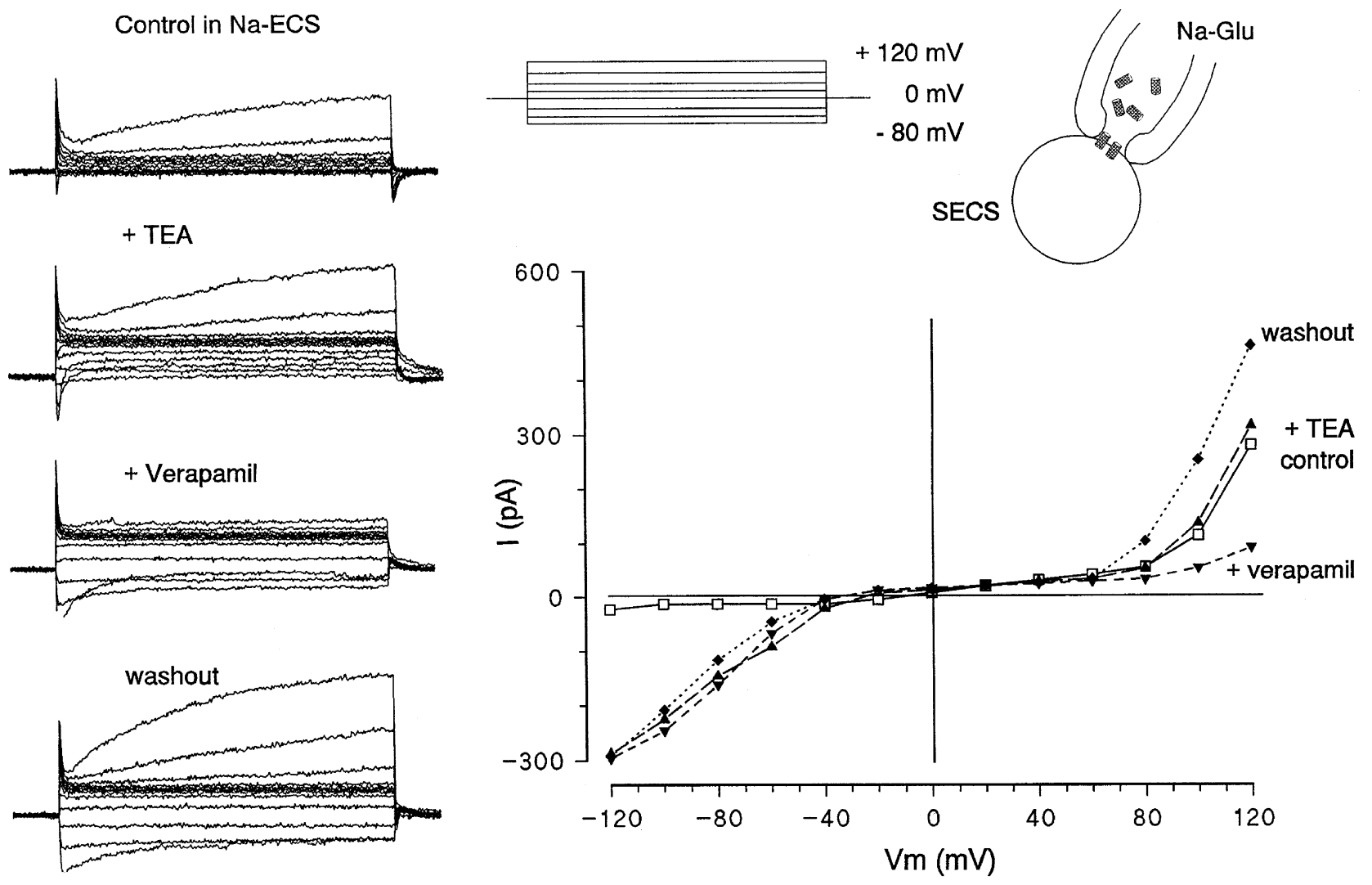

Fig. 1. Whole-cell currents representing a slowly activating outward current $\left(\mathrm{I}_{\text {slow }}\right)$ present in embryonic chicken osteoclasts. The pipette solution was Nagluconate-ICS, and the cells were bathed in Na-ECS. $2 \mathrm{~s}$ long voltage steps were applied to values of -80 to $+140 \mathrm{mV}$ from a holding potential of $0 \mathrm{mV}$. $50 \mu \mathrm{M}$ verapamil blocked the current. The measurements were made in nystatin whole-cell configuration. Current-voltage relationship of the whole-cell currents shown in the right panel. Current amplitudes were measured at the end of the voltage pulse 
apamilhydrochloride $2.5 \mathrm{mg} / \mathrm{ml}$ ) was purchased from Knoll AG, Ludwigshafen, Germany, SITS from Calbiochem, La Jolla, Ca, USA. Pooled data are given as means \pm standard deviations for a given number of cells: $M \pm$ S.D. (n).

\section{RESULTS \\ A slow outward current $\left(\mathrm{I}_{\mathrm{slo}}\right)$}

Three distinct potassium conductances have previously been described in chicken osteoclasts [22]. In an attempt to study possible anion currents in isolation, potassium ions were removed from intra- and/or extracellular solutions. Under these, high intracellular sodium conditions, a yet unknown outward current became apparent (Fig. 1). This outward current was observed in every osteoclasts $(n>50)$ and slowly activated at membrane potential $\mathrm{V}_{\mathrm{m}}>+44 \pm 12 \mathrm{mV}(\mathrm{n}=31)$. The time course of activation of the current could be fitted by a single exponential function and the time to half activation of the current was voltage-dependent $(350 \mathrm{~ms}$ at $+80 \mathrm{mV}$ and $78 \mathrm{~ms}$ at $+120 \mathrm{mV}$ ). In contrast to the slow activation kinetics, the current deactivated almost instantaneously when the membrane potential was stepped to $V_{m}<+40 \mathrm{mV}$. Therefore, we were not able to study the selectivity of this conductance in detail by determining the reversal potential using tail current experiments. Reducing both $\left[\mathrm{Na}^{+}\right]_{0}$ and $\left[\mathrm{Cl}^{-}\right]_{0}$ to $10 \mathrm{mM}$ by replacement with sucrose $(\mathrm{n}=4)$ did not reduce $\mathrm{I}_{\text {slo, }}$, suggesting that the current is due to an outward flow of cations and not to inwardly flowing $\mathrm{Cl}^{-}$ions. No significant $\mathrm{I}_{\text {slo }}$ was observed with high $\mathrm{K}^{+} /$low $\mathrm{Na}^{+}$intracellular solutions (7-ICS, $n=24)$ which suggest that $I_{\text {slo }}$ is either Na-selective or is activated by high $\left[\mathrm{Na}^{+}\right]_{\mathrm{i}}$. Chicken osteoclasts express two outwardly rectifying potassium conductances [22]. To test whether a small sodium permeability of the sustained outwardly rectifying $\mathrm{K}^{+}$conductance $\left(\mathrm{G}_{\mathrm{kto}}\right)$ was responsible for $\mathrm{I}_{\text {slo }}$ we used TEA, which inhibits $\mathrm{G}_{\mathrm{ko}}$ and $\mathrm{G}_{\mathrm{kto}}$ completely [35]. Addition of $5 \mathrm{mM}$ TEA $(\mathrm{n}=5)$ to the bath did not reduce $I_{\text {slo }}$ (not shown). Application of $50 \mu \mathrm{M}$ extracellular verapamil $(n=26)$, which blocked $G_{\text {kto }}$, reversibly blocked $I_{\text {slo }}$ (Fig. 1), but in contrast to $G_{\text {kto, }}, I_{\text {slo }}$ did not inactive during periods up to $5 \mathrm{~s}$ and $\mathrm{I}_{\text {slo }}$ was not dependent on the holding potential. Based upon these observations we conclude that embryonic chicken osteoclasts express another outwardly rectifying conductance besides the previously described $\mathrm{G}_{\mathrm{ko}}$ and $\mathrm{G}_{\mathrm{kto}}$. The inhibition of $\mathrm{I}_{\text {slo }}$ by extracellular verapamil allowed us to study osteoclast anion conductances in isolation.

\section{A hypoosmolality induced current $\left(\mathrm{I}_{\mathrm{osmo}}\right)$}

The hypoosmolality induced current $\mathrm{I}_{\text {osmo }}$ was first recognized in some chicken osteoclasts as a SITS blockable, outward background current, developing in conventional whole-cell experiments, when the pipette solution was slightly hypertonic. The study of Kelly et al. [15] on a similar current in rabbit osteoclasts did raise the question whether the presence of the underlying conductance, $\mathrm{G}_{\mathrm{osmo}}$, is a general feature 
A
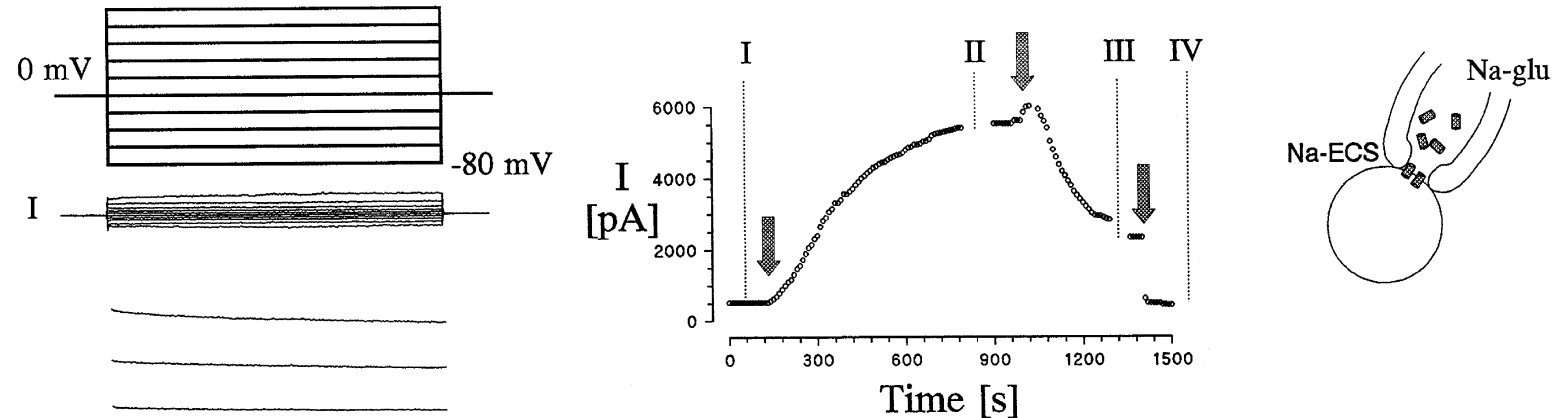

II

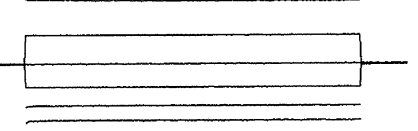

III

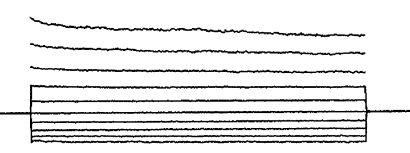

IV
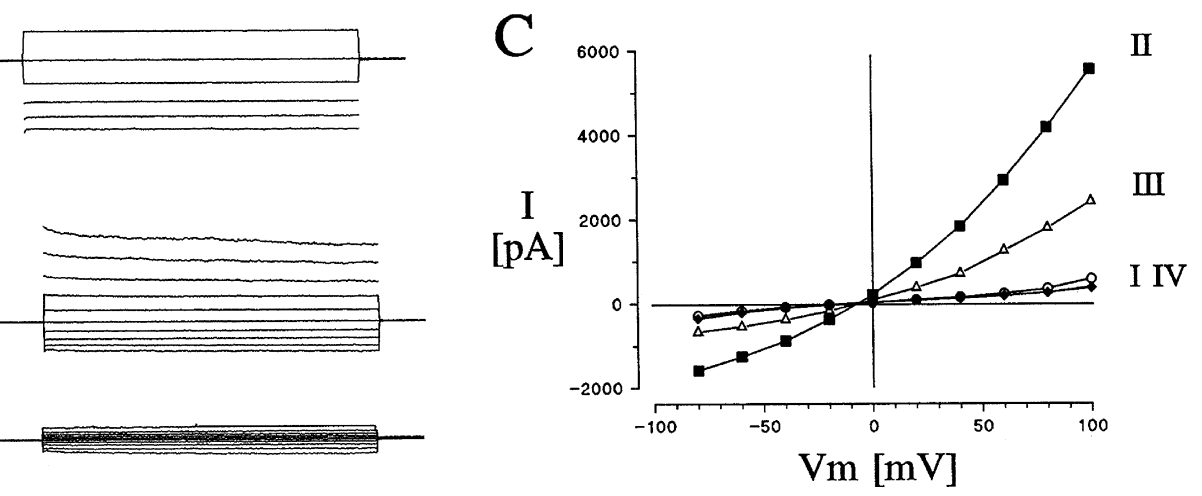

Fig. 2. Hypoosmolality induced whole-cell current $\left(\mathrm{I}_{\text {osmo }}\right)$ in an embryonic chicken osteoclast. The pipette solution was Na-gluconate-ICS, and the cells were bathed in Na-ECS. $2 \mathrm{~s}$ long voltage steps were applied to values of -80 to $+100 \mathrm{mV}$ from a holding potential of $0 \mathrm{mV}$. Whole-cell currents (Panel A, I., II., III., IV.) were recorded in the presence of $50 \mu \mathrm{M}$ verapamil. The development of the current was monitored by applying short (100 ms) pulses from a holding potential of $0 \mathrm{mV}$ to $+40 \mathrm{mV}$ (Panel B). Arrow indicates the application of hypoosmolality ( $225 \mathrm{mOsm})$ at $100 \mathrm{sec}$, hyperosmolality (340 mOsm) at $1000 \mathrm{sec}$ and $0.5 \mathrm{mM}$ SITS at $1400 \mathrm{sec}$. During the gaps before the solution exchange IV curves were recorded. The measurements were made in nystatin whole-cell configuration. Current-voltage relationship of the whole cell currents is shown in panel C 
of vertebrate osteoclasts serving a specific osteoclast related function. Therefore, we explored and characterised this conductance in embryonic chicken osteoclasts by applying hypotonic extracellular solutions during nystatin and conventional wholecell experiments.

In a first set of experiments Na-ECS bath and Na-ICS pipette solutions were applied to remove all $\mathrm{K}^{+}$currents. The above described $\mathrm{I}_{\text {slo }}$ current was present in all cells and was inhibited by verapamil. Application of a hypotonic shock $(75 \% \mathrm{Na}-$ ECS and $\left.25 \% \mathrm{H}_{2} \mathrm{O}\right)$, another current developed over time $(\mathrm{n}=25$ of 25 , see Fig. $2 \mathrm{~A}, \mathrm{~B})$.

Upon application of positive voltage steps, the current activated rapidly (within a few $\mathrm{ms}$ ) and did not inactive during periods up to $5 \mathrm{~s}$. The $\mathrm{I}-\mathrm{V}$ curve (Fig. $2 \mathrm{C}$ ) showed that the underlying $\mathrm{G}_{\text {osmo }}$ is slightly outwardly rectifying. Using osmotically balanced (by sucrose) extra- and intracellular solutions the current could not be observed $(\mathrm{n}=5)$. The current also did not develop in osmotically balanced but low ionic strength solutions (the sodium component of the Na-ECS and Na-ICS was partially or totally replaced with sucrose), indicating, that ionic strength of the solutions has no effect on the development of the current $(n=3)$. Subsequent application of hypotonic shock resulted in the activation of $\mathrm{I}_{\text {osmo, }}$, demonstrating that the current was present in these cells.

The time course of the development of $\mathrm{I}_{\text {osmo }}$ after hypo-osmotic shock is shown in Fig. 2B. The development of $\mathrm{I}_{\mathrm{osmo}}$ in time could be fitted with the next function, $\mathrm{I}_{\text {osmo }}(\mathrm{t})=\mathrm{I}_{\max } * 1 /\left\{1+\exp \left[-\mathrm{K}^{*}\left(\mathrm{t}-\mathrm{t}_{50}\right)\right]\right\}$. Half-maximal activation occurred at $\mathrm{t}_{50}=4.4 \pm 0.9 \mathrm{~min}(\mathrm{n}=9)$ and the steepness factor, $\mathrm{K}$, was $0.69 \pm 0.29 \mathrm{~min}^{-1}$. After the reintroduction of Na-ECS, supplemented with $10 \mathrm{mM}$ sucrose, a transient small increase of the current, presumably due to the increased external $\mathrm{Cl}^{-}$concentration was observed (Fig. 2B) followed by a decline of $\mathrm{I}_{\text {osmo. }}$. The time course of the decline of the current after applying 10 mOsm hyperosmolality could not easily be fitted, therefore we measured the time to $50 \%$ decrease of the current. The time to half deactivation was $130 \mathrm{~s}$. The decrease of $\mathrm{I}_{\text {osmo }}$ was only partial.

A possible mechanism for $\mathrm{G}_{\text {osmo }}$ activation is the swelling of the cells in hypotonic environment. During the experiment we frequently observed an increase in cell diameter, suggesting that membrane stretch may be necessary for the activation of the conductance.

Cytochalasin D, an inhibitor of polymerization of actin filaments, was used to test whether the integrity of the cytoskeleton was required for the activation of $\mathrm{I}_{\text {osmo. }}$. Pretreatment of osteoclasts with $50 \mu \mathrm{M}$ cytochalasin D $(\mathrm{n}=3)$, did not have effect on the time course of activation of $\mathrm{I}_{\text {osmo }}$.

\section{Pharmacology of $\mathrm{I}_{\text {osmo }}$}

Extracellular SITS $(0.5 \mathrm{mM})$ blocked $(95 \%)$ the current $(\mathrm{n}=15)$, and after washout the current partially recovered (up to $50 \%$ of its original value). Repeated applications of the SITS always blocked the current and after washout the current recovered 


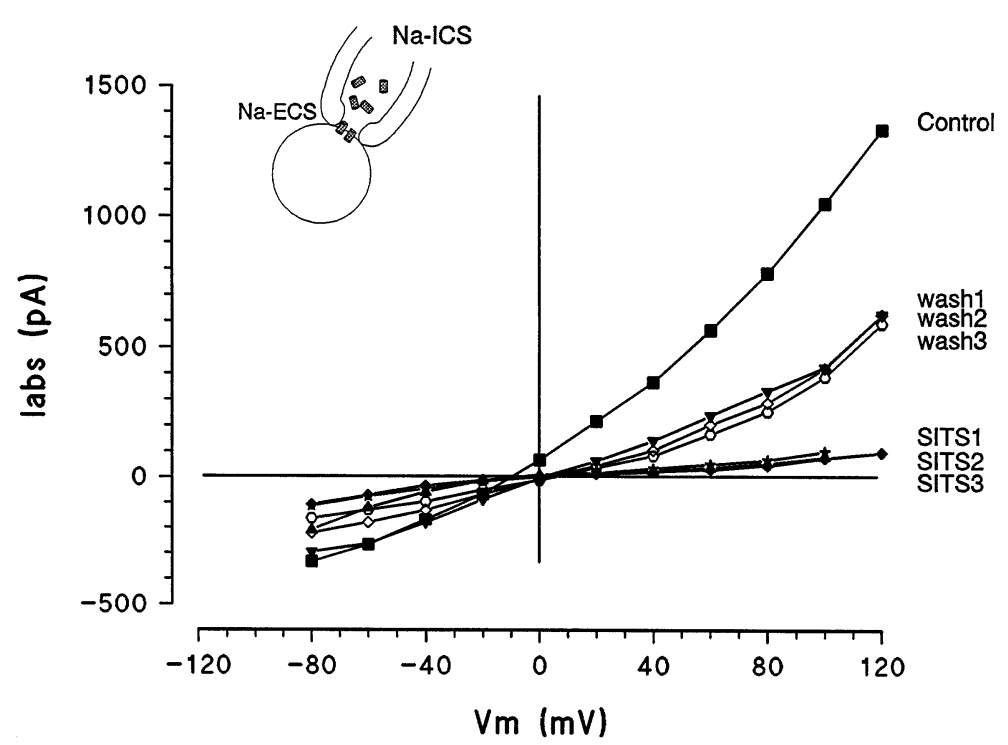

Fig. 3. Effect of repeated applications of SITS on the hypoosmolality ( $225 \mathrm{mOsm})$ induced anion conductance. The measurements were made in nystatin whole-cell configuration using $\mathrm{NaCl}-\mathrm{ICS}$ and $\mathrm{NaCl}-$ ECS solutions. $2 \mathrm{~s}$ long voltage steps were applied to values of -80 to $+120 \mathrm{mV}$ from a holding potential of $0 \mathrm{mV}$

to the same value as after the first washout of the blocker (Fig. 3). The blocking effect of the SITS was instantaneous. The channel blockers, verapamil $(50 \mu \mathrm{M}, \mathrm{n}=25)$, TEA $(5 \mathrm{mM}, \mathrm{n}=5), 4-\mathrm{AP}(5 \mathrm{mM}, \mathrm{n}=5), \mathrm{Ba}^{2+}(1 \mathrm{mM}, \mathrm{n}=5)$ did not have effect on the current.

Bisphosphonates are known to inhibit bone resorption, but its mode of action is not yet clear. One mechanism could be a block of $\mathrm{Cl}^{-}$channels causing less efficient electrogenic proton pumping by inhibiting charge neutralization. We therefore tested whether alendronate (ALN), a potent amino-bisphosphonate compound, would prevent activation of $\mathrm{I}_{\text {osmo. }}$. Pretreatment with ALN did not prevent the development of hypotonic shock induced anion current, when applied $0.5 \mathrm{mM}$ intra- $(\mathrm{n}=6)$ or extracellularly $(\mathrm{n}=5)$, using conventional whole cell configuration.

\section{Selectivity of $\mathrm{G}_{\mathrm{osmo}}$}

The hypotonic shock induced current reversed around the reversal potential calculated from the Nernst equation for $\mathrm{Cl}^{-}$(calculated $\mathrm{E}_{\mathrm{Cl}}=+8.2 \mathrm{mV}$ and measured $\mathrm{V}_{\text {rev }}=+5.4 \pm 3.6 \mathrm{mV}, \mathrm{n}=9$ ) and far from $\mathrm{E}_{\mathrm{K}}=$ not defined, $\mathrm{E}_{\mathrm{Na}}=-7.3 \mathrm{mV}$, and $\mathrm{E}_{\mathrm{Ca}}>90 \mathrm{mV}$. Using symmetric $\mathrm{Cl}^{-}$concentration in the bath and the pipette the current reversed at $0 \mathrm{mV}$ (conventional whole cell configuration, $\mathrm{n}=5$ ). To test whether there is any cation component of the current, Na-ECS solution was replaced with 


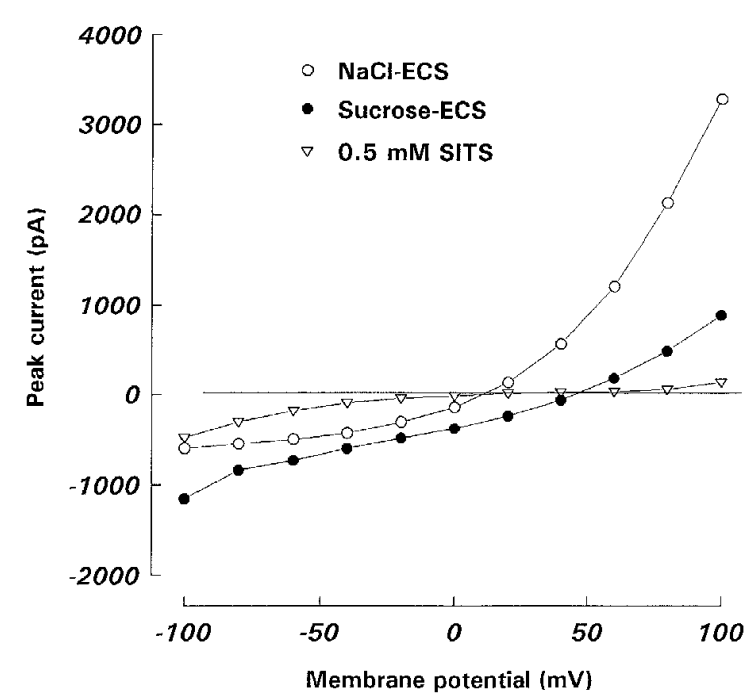

Fig. 4. Partial replacement of the extracellular $\mathrm{Cl}^{-}$by sucrose using sucrose-ECS (see Table 1) resulted in a shift toward a more positive value of the reversal potential. In the presence of sucrose-ECS, the current reversed at $+48 \mathrm{mV}$, which is the calculated reversal potential for $\mathrm{Cl}^{-}(48.26 \mathrm{mV})$. The measurements were made in conventional whole-cell configuration using NaCl-ICS and NaCl-ECS solutions. $2 \mathrm{~s}$ long voltage steps were applied to values of -80 to $+120 \mathrm{mV}$ from a holding potential of $0 \mathrm{mV}$. $0.5 \mathrm{mM}$ SITS blocked the current

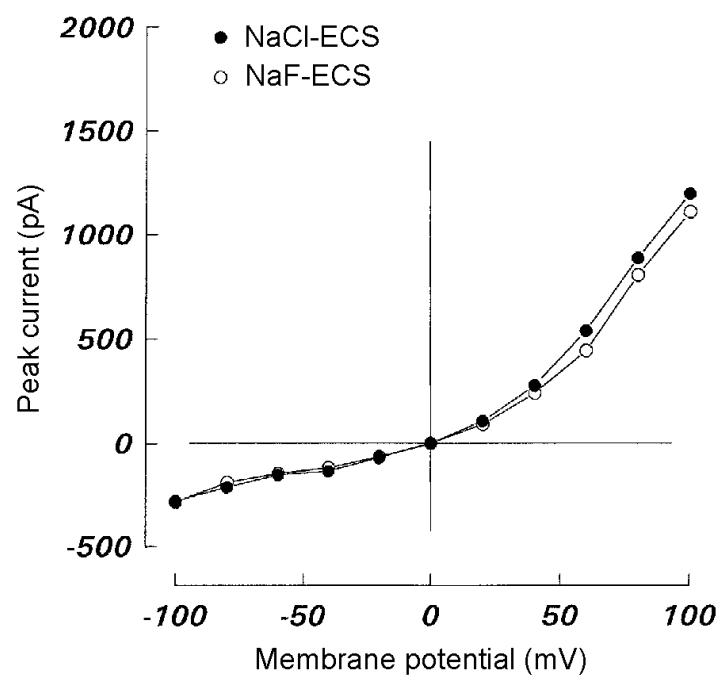

Fig. 5. The hypoosmolality induced conductance conducts fluoride ions as good as chloride ions. Measurements were made in nystatin-whole cell configuration using NaCl-ICS and NaCl-ECS solutions. The $\mathrm{NaCl}$-ECS was then replaced by NaF-ECS. $2 \mathrm{~s}$ long voltage steps were applied to values of -80 to +120 $\mathrm{mV}$ from a holding potential of $0 \mathrm{mV}$ 


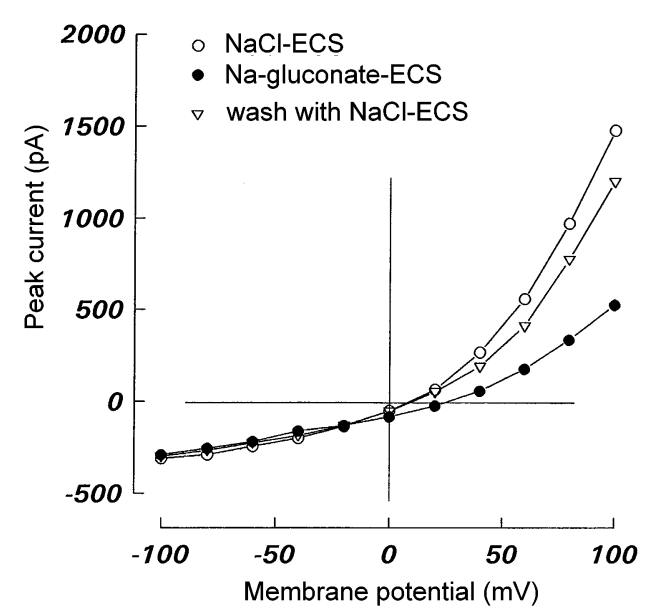

Fig. 6. The replacement of the NaCl-ECS by Na-gluconate-ECS resulted in a decrease of the outward current and in a shift toward a more positive value of the reversal potential. The inward current remained the same. Measurements were made in nystatin whole-cell configuration using NaCl-ICS and NaCl-ECS solutions. The NaCl-ECS was then replaced with NaF-ECS. 2 s long voltage steps were applied to values of -80 to $+120 \mathrm{mV}$ from a holding potential of $0 \mathrm{mV}$

sucrose-ECS after the development of the current. Sucrose-ECS containing $19 \mathrm{mM}$ $\mathrm{Cl}^{-}$, shifted the reversal potential of the hypoosmolality induced current (Fig. 4) to $+48 \mathrm{mV} \pm 3.7(\mathrm{n}=4)$. This is close to the predicted $\mathrm{E}_{\mathrm{Cl}}=53.8 \mathrm{mV}$ and not to the predicted $\mathrm{E}_{\mathrm{Na}}^{+}$of $-58.2 \mathrm{mV}$.

The relative anion selectivity of the conductance was also tested. Replacing the extracellular NaCl-ECS with NaF-ECS caused no change in the reversal potential $(\mathrm{n}=3)$, indicating that fluoride ions have the same permeability as chloride ions through the channel (Fig. 5). Replacing extracellular chloride with gluconate ions (glu-ECS) resulted in a decrease of the outward current and shifted $\mathrm{E}_{\text {rev }}$ to around $20 \mathrm{mV} \pm 2.4(\mathrm{n}=3)$ (Fig. 6). The permeability ratios $\mathrm{P}_{\mathrm{an}} / \mathrm{P}_{\mathrm{Cl}}$ calculated using the Goldman-Hodgkin-Katz voltage equation were 1.04 for $\mathrm{P}_{\mathrm{F}} / \mathrm{P}_{\mathrm{Cl}}$ while 0.46 for $\mathrm{P}_{\text {gluc }} / \mathrm{P}_{\mathrm{Cl}}$ thus $\mathrm{G}_{\text {osmo }}$ is an anion conductance, conducting $\mathrm{Cl}^{-}$ions and having a selectivity sequence $\mathrm{P}_{\mathrm{Cl}} \approx \mathrm{P}_{\mathrm{F}}>\mathrm{P}_{\text {gluc }} \gg \mathrm{P}_{\mathrm{Na}}$.

\section{DISCUSSION}

The main result of the present study is the finding of two, hitherto unknown conductances in chicken osteoclasts, a slow, outwardly rectifying conductance $\left(\mathrm{G}_{\text {slo }}\right)$, and a hypotonic shock induced anion conductance $\left(\mathrm{G}_{\mathrm{osmo}}\right)$.

In our experiments all three types of potassium channels described by Ravesloot et al. [22] were found in the examined cells when we used S-ECS and S-ICS solu- 
tions. To eliminate these potassium currents, symmetrical $\mathrm{NaCl}$ solutions were applied. Under these conditions an outwardly rectifying current was observed at potentials $>40 \mathrm{mV}$ which could effectively be blocked by $50 \mathrm{mM}$ verapamil. The current activated in the same membrane potential range as $\mathrm{G}_{\mathrm{ko}}$. The conductance, $\mathrm{G}_{\mathrm{slo}}$, described in this paper is different from $\mathrm{G}_{\mathrm{ko}}$, because of the following reasons: $(a)$ $\mathrm{G}_{\mathrm{slo}}$ has much slower activation kinetics than $\mathrm{G}_{\mathrm{ko}}(>200 \mathrm{~ms}$ vs $20 \mathrm{~ms}),(b) 5 \mathrm{mM}$ TEA had no effect on $\mathrm{G}_{\text {slo }}$, while it completely blocks $\mathrm{G}_{\mathrm{ko}},(c) 50 \mathrm{mM}$ Verapamil blocks $\mathrm{G}_{\text {slo, }}$, while it has no effect on $\mathrm{G}_{\mathrm{ko}}$ [35]. The slow activation kinetics of $\mathrm{I}_{\text {slo }}$ at $\mathrm{Vm}>$ $+40 \mathrm{mV}$ is quite distinct from other conductances present in osteoclasts as well as other cells. A proton conductance $\left(\mathrm{G}_{\mathrm{H}}\right)$, with similar slow activation kinetics, has been identified in mammalian osteoclasts and human neutrophils $[8,21]$. The proton conductance in rabbit osteoclasts activated at $\mathrm{Vm}>0 \mathrm{mV}$ and was inhibited by 0.5 $\mathrm{mM} \mathrm{Zn}{ }^{2+}$. But in contrast to $\mathrm{I}_{\text {slo }}$ in chicken osteoclasts, the proton current in rabbit osteoclasts had a clear tail current. However, under normal potassium gradients, we did not observe a current component similar to $I_{\text {slo }}$ in chicken osteoclasts. Further experiments are required to elucidate properties of $\mathrm{I}_{\text {slo }}$ in avian osteoclasts.

The hypotonic shock induced anion channels and currents are present in various types of cells [1, 3, 7, 11, 18, 19, 20, 27, 33]. Hypoosmolality induced chloride conductances were also found in rat and rabbit osteoclasts $[15,25]$. In our experiments exposure of the osteoclasts to hypotonic solution resulted in the activation of an anion conductance. Using isotonic extra- and intracellular solutions the current could never be observed. Applying low ionic strength but isotonic solutions the current did not develop, indicating that ionic strength has no effect on the development of the current. After activation of $\mathrm{I}_{\mathrm{osmo}}$, the current decreased by changing the bath medium with hypertonic solutions.

In our measurements the chloride current developed after a 50-60 sec delay and reached its maximum within 10 minutes. In endothelial cells the process reached its maximum within 2 minutes [26]. A reason of the difference in the development of the current can be the different size and volume of the cells (the osteoclasts size was in the range of 30-100 mm diameter). Villaz et al. [32] reported on a voltage gated inwardly rectifying chloride current is ascidian embryos that is modulated by both the cell cycle and cell volume. He found that the increase in diameter that was complete in $10 \mathrm{~s}$, suggesting the involvement of a second messenger system in the response. Interestingly, Fujita et al. [10] described a DIDS blockable, outwardly rectifying $\mathrm{Cl}^{-}$conductance in freshly isolated rabbit osteoclasts which was activated after increasing $\left[\mathrm{Ca}^{2+}\right]_{0}$ from 1 to $20 \mathrm{mM}$.

This $\mathrm{Cl}^{-}$conductance could also be activated by GTP $\gamma \mathrm{S}$ without increasing $\left[\mathrm{Ca}^{2+}\right]_{0}$. They found that an increase of the intracellular $\mathrm{Ca}^{2+}$ concentration was required for the activation of the current. In our experiments using conventional whole-cell conditions (10 mM EGTA in the pipette) the $\mathrm{Ca}_{\mathrm{i}}$ did not change during the development if $\mathrm{I}_{\text {osmo. }}$. A further mechanism for regulation of the chloride conductance is suggested by Shankar et al. [25] who demonstrate that RGD containing peptides binding to integrins prevent the activation of osmo-induced currents. 
Whether the $\mathrm{Ca}^{2+}$-activated $\mathrm{Cl}^{-}$conductance in rabbit osteoclasts [10] is different from the hypotonic shock induced $\mathrm{Cl}^{-}$conductance [15] in the same cells is unclear. Both have similar electrophysiological properties and are blocked by DIDS. It is possible that there is one $\mathrm{Cl}^{-}$conductance, which can be activated by different signaling mechanism.

While Sims et al. (1991) found an outwardly rectifying $\mathrm{Cl}^{-}$conductance in freshly isolated rat osteoclasts, the $\mathrm{I}_{\text {osmo }}$ in chicken osteoclasts could be observed both directions, although a limited outward rectification was noticed. As in case of the $\mathrm{Cl}^{-}$ current described for rat osteoclasts [29] the current observed by us could also be blocked by SITS (Fig. 3).

Based on the following lines of evidence we assume that the observed hypoosmosis induced anion current is a stretch activated conductance: $A$. In conventional and nystatin whole-cell configuration the same current could be observed, indicating that no second messenger system is involved. $B$. The increase of the cell size could be observed during the development of the current on a comparable time scale. $C$. Hyperosmosis reduced the current without a reasonable delay.

The exact functional role of chloride channels in osteoclasts remains to be determined. However, there are direct and indirect evidence that chloride channels play an important role in osteoclasts. Chloride channels are important for mediating chloride efflux during regulatory volume decrease after hypotonic shock in many cells including osteoclasts. The efficiency of proton pumping in the ruffled border membrane of chicken osteoclasts are dependent on a $\mathrm{Cl}^{-}$permeability [5]. Without charge compensation, the proton pump cannot work. And finally, the stilbenes DIDS and SITS were shown to reduce bone resorption $[13,16]$. The reduction in resorption was attributed to the inhibition of $\mathrm{Cl}^{-} / \mathrm{HCO}_{3}^{-}$exchangers, which are abundantly present in osteoclasts. There is a possibility that DIDS and SITS inhibit the electrogenic proton extrusion by blocking the chloride channel, because there is evidence that the activity of the proton pump of osteoclasts is strictly dependent upon $\mathrm{Cl}^{-}$ions [5].

The observed anion conductance reversed at the calculated $\mathrm{Nernst}^{-} \mathrm{Cl}^{-}$potential. When the ${ }^{\left.\mathrm{Cl}^{-}\right]}$was not equal in the extra- and intracellular solutions the reversal potential shifted in the direction expected for the chloride reversal potential. This observation is in agreement with the results of De Smet et al. [26] who measured $-4 \pm 2 \mathrm{mV}$ difference between the calculated and measured $\mathrm{V}_{\text {rev }}$ of the hypotonic shock induced $\mathrm{Cl}^{-}$current on endothelial cells. Because of the small deviation among the measured and calculated reversal potentials it is very likely that other currents than $\mathrm{Cl}^{-}$are not activated by hypotonic shock.

Maxi chloride channels were shown to be present in both rat and chicken osteoclasts $[24,35]$. These $\mathrm{Cl}^{-}$channels have a single channel conductance around $350 \mathrm{pS}$ and were only found in excised membrane patches. Our results suggest, that a small conductance channel underlies the macroscopic current described in this paper. The properties of the hypotonic shock induced anion current $\left(\mathrm{I}_{\text {osmo }}\right)$ characterised here are different from those of the high conductance anion channels (HCAC). Deactivation at hyperpolarizing potentials observed in HCAC was not found in $\mathrm{I}_{\text {osmo. }}$. The maximum conductance of our cells was between 4 and $75 \mathrm{nS}$, which corresponds with 11 
to 214 HCAC channels of $350 \mathrm{pS}$. Due to the high membrane resistance of our cells, we would have been able to measure currents through single channels of $350 \mathrm{pS}$ in our whole-cell recordings. We never found any channel opening or closing events during our whole-cell current records when $\mathrm{G}_{\text {osmo }}$ was active. The noise level of $\mathrm{G}_{\text {osmo }}$ is very low, which would be inconsistent with opening and closing events of the maxi chloride channels. Current through maxi- $\mathrm{K}^{+}$channels $(150 \mathrm{pS})$ in chicken osteoclasts results in high noise levels of the whole-cell current $[22,34]$.

Based on the above observations it is more likely that a small conductance anion channel is responsible for the $\mathrm{G}_{\text {osmo, }}$, similar to the $20 \mathrm{pS}$ found in rabbit osteoclasts [15]. The hypotonic shock induced anion conductance is not very selective for anions. Fluoride ions pass as well as chloride ions and even larger anions like gluconate permeate through the channel, although, with a lower rate.

In conclusion, we have provided evidence that freshly isolated embryonic chicken osteoclasts exhibit an outwardly rectifying conductance in symmetrical $\mathrm{NaCl}$ solutions, and a hypotonic shock induced anion conductance. The latter one is not very selective, therefore could provide pathways for other anions into and from the resorption lacuna. Besides maintaining electroneutrality the $\mathrm{Cl}^{-}$current may have another important function. The chloride efflux would prevent accumulation of internal $\mathrm{Cl}^{-}$, due to the $\mathrm{Cl}^{-} / \mathrm{HCO}_{3}^{+}$exchange. As in other cells, chloride current of the osteoclasts may be regulated by cytosolic second messenger [6] that provide the possibility of $\mathrm{Cl}^{-}$conductance to modulate bone resorption. Selective blockers of anion conductances in osteoclasts may be clinically useful to prevent excessive bone resorption.

\section{ACKNOWLEDGEMENT}

This work was partially supported by OTKA Grants T029947 and T022435, ETT, T10/104/2000, and FKFP Grant 322/2000.

\section{REFERENCES}

1. Banderali, U., Roy, G. (1992) Activation of $\mathrm{K}^{+}$and $\mathrm{Cl}^{-}$channels in MDCK cells during volume regulation in hypotonic media. J. Membrane Biol. 126, 219-234.

2. Baron, R., Neff, L., Louvard, D., Courtoy, P. J. (1985) Cell-mediated extracellular acidification and bone resorption: evidence for a low $\mathrm{pH}$ in resorbing lacunae and localization of a $100-\mathrm{kD}$ lysosomal membrane protein at the osteoclasts ruffled border. J. Cell Biol. 101, 2210-2222.

3. Best, L., Benington, S. (1998) Effects of sulphonylureas on the volume sensitive anion channel in rat pancreatic beta-cells. Br. J. Pharmacol. 125, 874-878.

4. Blair, H. C., Teitelbaum, S. L., Ghiselli, R., Gluck, S. (1989) Osteoclastic bone resorption by a polarized vacuolar proton pump. Science 245, 855-857.

5. Blair, H. C. Teitelbaum, S. L., Tan, H. L., Koziol, C. M., Schlessinger, P. H. (1991) Passive chloride permeability charge coupled to $\mathrm{H}^{+}$-ATPase of avian osteoclast ruffled membrane. Am. J. Physiol. 260, 1315-1324.

6. Chesnoy-Marchais, D., Fritsch, J. (1989) Chloride current activated by cyclic AMP and parathyroid hormone in rat osteoblast. Pflugers Arch. 415, 104-114. 
7. Christensen, O., Hoffman, E. K. (1992) Cell swelling activates $\mathrm{K}^{+}$and $\mathrm{Cl}^{-}$channels as well as nonselective, stretch activated cation channels in Ehrlich ascites tumor cell. J. Membr. Biol. 129, 13-36.

8. De Coursey, T. E., Cherny, V. V. (1994) $\mathrm{Na}(+)-\mathrm{H}+$ antiport detected through hydrogen ion currents in rat alveolar epithelial cells and human neurophils. J. Gen. Physiol. 103, 755-785.

9. Fritsch, J., Edelman, A. (1997) Osmosensitivity of the hyperpolarization-activated chloride current in human intestinal T48 cells. Am. J. Physiol. 272, 778-786.

10. Fujita, H., Matsumoto T., Kawashima, H., Ogata, E., Fujita, T., Yamashita, N. (1996) Activation of $\mathrm{Cl}^{-}$channals by extracellular $\mathrm{Ca}^{2+}$ in freshly isolated rabbit osteooclasts. J. Cell. Physiol. 169, $217-$ 225.

11. Gallin, E. K., Mason, T. M., Mora, A. (1994) Characterization of regulatory volume decrease in THP1 and HL-60 human myelotic cell lines. J. Cellular Physiol. 159, 573-581.

12. Gáspár, R. Jr., Weidema, A. F., Krasznai, Z., Nijweide, P. J., Ypey, D. L. (1995), Tetrodotoxin-sensitive fast $\mathrm{Na}^{+}$current in embryonic chicken osteoclasts. Pflügers Arch. 430, 596-598.

13. Hall, T. J., Chambers, T. J. (1989) Optimal bone resorption by isolated rat osteoclasts requires chloride bicarbonate exchange. Calcif. Tissue Int. 45, 378

14. Hamil, O. P., Marty, A., Neher, E., Sakman, B., Sigworth, F. J. (1981) Improved patch-clamp techniques for high-resolution current recording from cells and cell-free membrane patches. Pflügers Arch. 391, 85-100

15. Kelly, M. E., Dixon, S. J., Sims, S. M. (1994) Outwardly rectifying chloride current in rabbit osteoclasts is activated by hypoosmotic stimulation. J. Physiol. 475, 377-389.

16. Klein-Nulend, J., Raisz, L. G. (1989) Effects of two inhibitors on anion transport on bone resorption in organ culture. Endocronology 125, 1019.

17. Korn, S. J., Marty, A., Connor, J. A., Horn, R. (1991) Perforated patch recording. Methods. Neurosci. 4. 363-373.

18. Lewis, R. S., Ross, P. E., Cahalan, M. (1993) Chloride channels activated by osmotic stress in lymphocytes. J. Gen. Physiol. 101, 801-826.

19. Nilius, B., Olike, M., Zahradnik, I., Droogmans, G. (1994) Activation of a $\mathrm{Cl}^{-}$current by hypoosmotic volume increase in human endothelial cells. J. General Physiol. 103(5), 787-805.

20. Nilius, B., Prenen, J., Kamouchi, M., Voets, T., Droogmans, G. (1997) Inhibition by mibefradil, a novel calcium channel antagonist of $\mathrm{Ca}^{2+}$ and volume activated $\mathrm{Cl}^{-}$channels in macrovascular endothelial cells. Br. J. Pharmacol. 121, 547-555.

21. Nordstrom, T., Rotsein, O. D., Romanek, R., Asotra, S., Heersche, J. N., Manolson, M. F., Brisseau, G. F., Grinstein, S. (1995) Regulation of cytoplasmic pH in osteoclasts. Contribution of proton pumps and a proton-selective conductance. J. Biol. Chem. 270, 2203-2212.

22. Ravesloot, J. H., Ypey, D. L., Vrijheid-Lammers, T., Nijweide, P. J. (1989) Voltage activated $\mathrm{K}^{+}$conductances in freshly isolated embryonic chicken osteoclasts. Proc. Nat. Acad. Sci. USA 86, 68216825 .

23. Ravesloot, J. H., VanHouten, R., Ypey, D. L., Nijweide, P. J. (1991) High conductance anion channels in embryonic chick osteogenic cells. J. Bone Miner. Res. 6, 355-363.

24. Schoppa, N. A., Su, Y., Baron, R., Boulpaep, E. L. (1990) Identification of single channels in neonatal rat osteoclasts. J. Bone Mineral Res. 5. Suppl. 2. (abstract)

25. Shankar, G., Coetzwee, W. A., Horton, M. A. (1994) Rapid intracellular acidification and inhibition of strech-activated chloride currents by integrin ligands in rat osteoclasts. J. Bone Miner. Res. 9, 138, 115 .

26. De Smet, P., Oike, M., Droogmans, G., Van Driessche, W., Nilius, B. (1994) Responses of endothelial cells to hypotonic solutions: lack of regulatory volume decrease. Pflugers Arch. 428, 94-96.

27. Sims, S. M., Kelly, M. E., Arkett, S. A., Dixon, S. J. (1992) Electrophysiology of osteoclasts. In: Rifkin, B. R., Gays, C. V. (eds) Biology and Physiology of Osteoclasts CRC Press, Boca Raton. pp. 223-224.

28. Shennan, D. B. (1999) Properties of volume activated taurine and iodide efflux from term human placental tissue. Placenta 20, 485-491. 
29. Sims, S. M., Kelly, M. E., Dixon, S. J. (1991) $\mathrm{K}^{+}$and $\mathrm{Cl}^{-}$currents in freshly isolated osteoclasts. Pflügers Arch. 419, 358-370.

30. Steinert, M., Grissmer, S. (1997) Novel activation stimulus of chloride channels by potassium in human osteoblast and human leukaemic T lymphocytes. J. Physiol. Lond. 500, 653-660.

31. Vaes, G. (1989) Cellular biology and biochemical mechanism of bone resorption. A review of recent developments on the formation, activation and mode of action of osteoclasts. Clin. Orthop. 231, 239-271.

32. Villaz, M., Cinniger, J. C., Moodt, W. J. (1995) A voltage-gated chloride channel in ascidian embryos modulated by both the cell cycle clock and cell volume. J. Physiol. 488, 689-699.

33. Walker, V. E., Stelling, J. W., Miley, H. E., Jacob, T. J. (1999): Effect of coupling on volume-regulatory response ciliary epithelial cells suggests mechanism for secretion. Am. J. Physiol. 276, 14321438.

34. Weidema, A. F., Ravesloot, J. H., Panyi, G., Nijweide, P. J., Ypey, D. L. (1993) A Ca ${ }^{2+}$ dependent $\mathrm{K}^{+}$ channel in freshly isolated and cultured chicken osteoclasts. Biochem. Biophys. Acta 1149, 63-72.

35. Weidema, A. F., Krasznai, Z., Booj, P., Panyi, G., Gáspár, R., Nijweide, P. J., Ypey, D. L. (1996) Pharmacological properties of $\mathrm{K}^{+}$conductances in embryonic chicken osteoclasts. In: Weidema, A. F.: Ion channels and ion transport in chicken osteoclasts $\mathrm{Ph}$. D. Thesis, University of Leiden. The Netherlands.

36. Ypey, D. L., Weidema, A. F., Hold, K. M., VanderLaarse, A., Ravesloot, J. H., VanderPlas, A., Nijweide, P. J. (1992) Voltage, calcium and stretch activated ionic channels and intracellular calcium in bone cells. J. Bone Miner. Res. 7, S2, 377-387. 
